\title{
Ecosystem of Renewable Energy Enterprises for Sustainable Development: A Systematic Review
}

\author{
Carol Dineo Diale*,1, Mukondeleli Grace Kanakana-Katumba ${ }^{2}$, Rendani Wilson Maladzhi² \\ ${ }^{1}$ Department of Psychology, Industrial Psychology, Rhodes University, Grahamstown, 6139, South Africa \\ ${ }^{2}$ Department of Mechanical and Industrial Engineering, University of South Africa, Johannesburg, 0002, South Africa
}

A R T I C L E I N F O

Article history:

Received: 29 September, 2020

Accepted: 28 December, 2020

Online: 22 January, 2021

Keywords:

Renewable energy

Enterprise

Ecosystem

Sustainable development goals

\begin{abstract}
A B S T R A C T
In the Global sphere, the social, environmental, and economic pillars are the main contributors and accelerators to the sustainable development goals. As a result, the latter creates a platform for interdisciplinary researchers, society and decision-makers to collaborate in formulating ways to minimize factors contributing to environmental concerns. Energy is currently referred to as one of the scarce resources. The scarcity of electricity is mainly experienced in the rural areas of most countries in the world. The mandate of the green economy is to introduce innovative ways to redress the inequalities and lack of access, especially when it comes to Energy. Based on the sector's efforts, questions arise as to what comprises the ecosystem that can be accelerated to enhance entry to the sector. Hence, the researchers focus on Renewable Energy with specific reference to the entrepreneurial motives to meet sustainable goals. The applicable sustainable goals are goal 7 (affordable and clean Energy) and Goal 8 (decent work and economic growth). Furthermore, Energy contributes to modern access and poverty reduction to accelerate the transitioning to a Green economy. The current paper hopes to answer the following questions: Firstly, how Renewable Energy enterprise can contribute to sustainable development goals theoretically. Secondly, how can the theoretical energy enterprise ecosystem be contextualized in the South African context? A theoretical review was conducted through a literature review of which $n=47$ sources met the criteria that the researchers set for ecosystem variables. The overarching goal of the paper is premised on various works of literature building the ecosystem of the elements highlighted by most researchers in the field of renewable energy enterprises or business ventures. From the various models, the framework emerged singling out the critical success factors of the ecosystem of the Renewable Energy enterprise. The theoretical ecosystem consists of accelerators, social factors, sustainable development goals, as well as selected business models. The latter ecosystem was then contextualized in the South African context for a complete framework. Some of the critical drivers derived from the latter broad ecosystem are: Renewable Energy Feed-in Tarrif(REFIT), Utility Renewable Energy business model, Customer renewable energy business model, Energy Justice (distributive justice), Off-grid (Mini-grid), Saurian Lilting lamp, Renewable powered irrigation system.
\end{abstract}

\section{Introduction}

This current paper is emanating from the paper Green Entrepreneurship Model Utilising the System Dynamics Approach: A Review" presented at IEEM 2019 Conference in Macau [1]. There are always pressures around social, economic,

*Corresponding Author: Dineo Diale, c.diale@ru.ac.za

www.astesj.com

https://dx.doi.org/10.25046/aj060146 and political phenomena as part of the triple bottom [2] to meet the green economy expectations and ways were researchers, and society at large can contribute to the process. Figure 1 shows the data world rural electrification rate \& Electrification Growth rate.

Figure 1 illustrates the rural electrification and electrification growth rate from the 1990s to 2016. The red line demarcates rural electrification growth rate and the blue line demarcates rural 401 
electrification rate (percentage of rural population). Rural electrification is a process of giving access to the commodity to the population in rural areas $[3,4]$. Energy is one of scarce commodity, where millions of people, especially in the rural areas, are not connected to the electricity grid, due to lack of affordability [4].

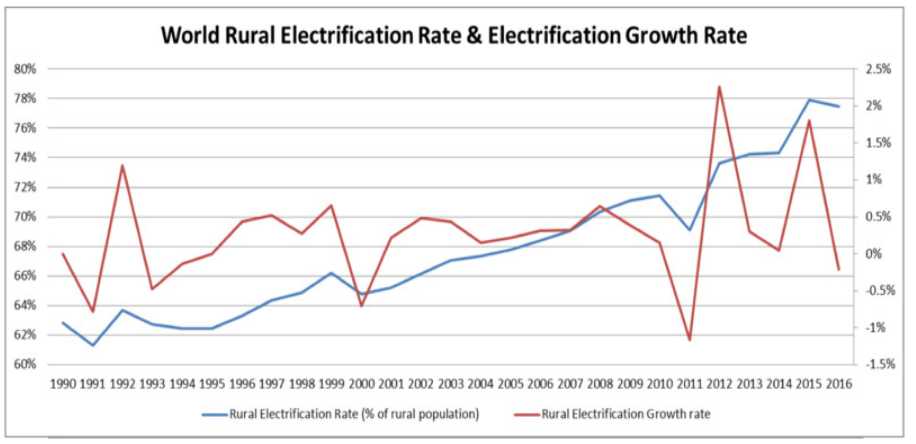

Figure 1: World Rural Electrification Rate \& Electrification Growth Rate [3].

The green economy's mandate is to introduce innovative ways to redress the inequalities and lack of access, especially when it comes to energy [5]. Large numbers of people use fires and fuel lighting for basic energy needs [2], particularly in rural areas. The success factors or contingency plans were then introduced as an alternative mechanism such as renewable energy [2]. The latter serves as an effort to ensure that everyone can be able to light their houses or businesses. In hoping to minimize the challenge of the majority of South Africans without access to electricity, the country has a solar park in the Northern Cape. The solar park is to improve living, promote sustainable tourism. The latter strategy attracts tourists and investors, contributing to the economy of the country [4].

Furthermore, from the efforts on the sector, questions arise as to what would be an ecosystem that can be accelerated to enhance entry to the sector. The current research proposes a focus on specific reference to the entrepreneurial motives in efforts to meet sustainable development goals. Efforts have been made to explore renewable energy enterprises $[6,7]$ but have not focused on sustainable development goals or social focus within the area. The applicable sustainable development goals identified are Goal 7 (Affordable and Clean Energy) as well as Goal 8 (Decent work and Economic growth) [8] Furthermore, Energy contributes to modern access, and poverty reduction [8-10], to accelerate the transitioning to Green economy. The idea is to focus on one Green economy thematic area, which is Energy, and refining the research to focus only on enterprise within the energy sector.

The paper is premised through various works of literature building the ecosystem, taking into consideration the elements highlighted by most researchers in the field of Renewable Energy enterprises or business ventures. From the various models, the framework emerged singling out the ecosystem of the Renewable Energy enterprise. The theoretical ecosystem consists of accelerators, societal factors, and sustainable development goals as well as selected business models. The latter ecosystem is then contextualized in the South African context for a complete framework. The subsequent section will focus on literature review, research questions, methodology, results and discussions, and future recommendations.

\section{Research questions}

The research questions were formulated through the research gaps that were identified while reviewing literature and where possible research contributions can be made setting future research agendas. The research questions are as follows:

- How can theoretical Renewable Energy enterprise ecosystem be contextualized in the South African context?

- How can Renewable Energy enterprise contribute to sustainable development theoretically?

\section{Research Background}

The Literature review discussed in the paper is premised on accelerators and barriers to the Renewable Energy in the formulation of key drivers which can be part of the framework. Furthermore, the theory behind the ideas on how Renewable Energy can be used to contribute to sustainable development goals will be discussed below.

\subsection{Accelerators to Renewable Energy}

Through the review of literature, support mechanism implemented worldwide are in the form of the non-financial and financial mechanism as well as strategic programmes [9-11]. A generic business framework such as utility renewable energy business and customer renewable energy business model has been developed to facilitate manufacturing to consumption value chain to support Renewable Energy enterprises in the international markets [12-14]. Due to the diffusion of energy supply, support as an investment can accelerate the planning and implementation of the scarce commodity [15].

Other factors such as the biographical determinants such as age, level of education have demonstrated to the adoption of Renewable Energy technology. The generation that tends to adopt to the technology has been proven to be the younger generation than the older generation [16].

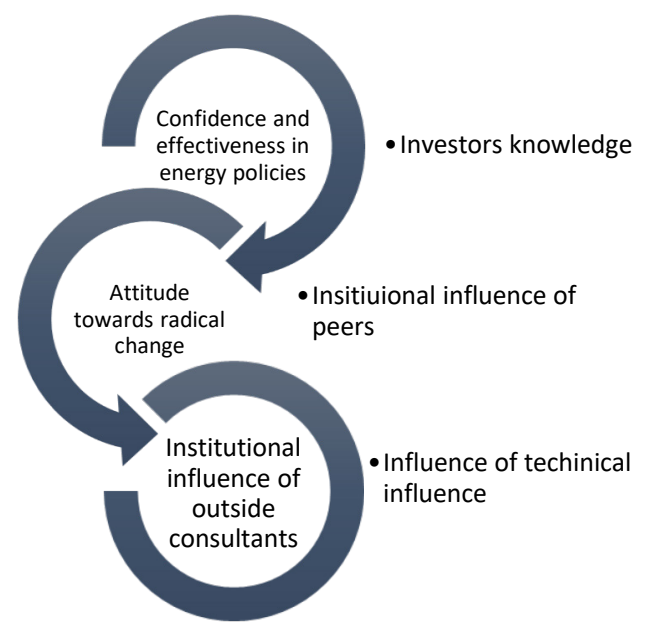

Figure 2: Renewable energy non-financial support mechanisms [15].

Figure 2 depicts the non-financial support mechanisms that could accelerate Renewable Energy. Scholars such as [15] have raised that non-financial support needs to be the cornerstone of the planning and implementation of Renewable Energy. The 
renewable Energy serves as a "new kid on the block"; therefore, scepticism comes somewhat derails the implementation.

\subsection{Access of the commodity by the society through sustainable development goals}

In contribution to the access of the commodity by the society, the authors are proposing using sustainable development goals as a framework. Thematic areas of the green economy are inclusive but not limited to Green Energy, sustainable water, waste, agriculture, trade-in low carbon products, cleaner and green technology, green buildings, green chemistry and sustainable transport (mini car/cycles) as well as air quality [17]. Enabling the green economy involves innovation [18] of which needs attention and serves as a research agenda.

There are 17 sustainable development goals namely: Goal 1 Eradication of poverty; Goal 2 No hunger, Goal 3 Good health, and well-being, Goal 4 Quality education, Goal 5 Gender equality, Goal 6 Clean water and sanitation, Goal 7 Affordable and clean energy, Goal 8 Decent work and economic growth, Goal 9 Industry, innovation and infrastructure, Goal 10 Reduced inequality, Goal 11 Sustainable cities and communities, Goal 12 Responsible consumption and production, Goal 13 Climate Action, Goal 14 Life below Water, Goal 15 Life on land, Goal 16 Peace and Justice and strong institutions, Goal 17 Partnerships to achieve a goal [19].

Efforts have been made to introduce Energy technologies and policies is to reduce poverty and facilitate Clean Energy [20]. The need to contribute to societal need by reducing the electricity bills for those who cannot afford them, serves as a crucial social context [21], needing collective actions and commitment of relevant stakeholders inclusive of professionals in the field of Industrial Psychology, Industrial engineering, Energy practitioners, community members, governments officials and politicians.

Understanding culture and community needs from a social perspective, spearheaded by social scientists to study the area of Renewable Energy in Sub Saharan Africa [21] is needed, of which the authors believe that this best practice could be implemented in the South African context, to understand and tailor services and products to society leveraging on societal needs. Accelerators and support for Renewable Energy need to be contextualized in Rural, Urban, and semi-rural areas to create the impact and effective implementation. To echo the latter statement, the study conducted in Bangladesh investigated the impact of the implementation of Renewable Energy in rural areas and found that Renewable Energy contributes to social, economic and environmental benefits [22].

The benefits of Renewable Energy can benefit people living in rural areas through better quality of living and health as the majority living in Bangladesh use kerosene, candle and often have to walk a long distance to fetch wood for cooking [22]. Renewable Energy through natural resources such as biogas, solar, wind, hydropower can benefit the society of rural of Bangladesh [22].

\subsection{Barriers to Renewable Energy}

Some of the challenges identified are wage or salary disparities, skills shortages, shortage of coal, producers, corruption, mismanagement of funds and resources, lack of policy framework, limited absorption of solar manufacturing plants [3]. Developing countries do not have adequate resources, such as technology, lack of institutional support, lack of skills and lack of regulatory policies especially when it comes to Renewable Energy $[23,24]$ of which the same challenges may be the case in the South African context.

The negative impact of oil prices fluctuation is affecting the economic and political sphere of the continent [25]. According to [26], investors from other continents are reluctant to do business in Africa.

The lack of competencies, failure to create a new value proposition, and competition have been demonstrated to serve as barriers in Renewable Energy ventures [6, 26, 27]. The cornerstone query of creating a market arises, in establishing potential customer clientele, as well as the capacity of understanding the importance of adoption of Renewable Energy and how the technology can be utilised to ensure effectiveness and viability of enterprises $[6,13,27,28]$.

Upon reviewing the literature scholars have demonstrated that the effect of price control, inability to adopt new technologies and lack of market diversification further added to the challenges of full implementation of Renewable Energy technologies [25].

Further barriers, especially in the African context, is the issue of connection to the grid, inability to build relationships with established companies, lack of trade and distribution organisations [23]. In the South African context, it was discovered that barriers in the Energy project are credit risk, market risk, risk of change of legislation as well as technological risks [29].

The lack of the necessary infrastructure and education has been found to be obstacles in quest of the adoption of Renewable Energy as technology [30]. Thus, From the research point of view, lack of research and innovative way incorporated within research methodologies to Renewable Energy as technology serves as a challenge. In [5], the author asserts that the specific research methodologies such as quantitative methodology forms part of the puzzle and may become a solution in implementing the Energy programmes. Further challenges that researchers raise are weak electricity grids, corruption as well as future entrepreneurs in the field of renewable Energy having challenges in handling the complexity of adoption of Renewable Energy as a technology [3, $5,25,26]$.

\section{Purpose statement}

Upon explaining the research background above, purpose statement is then formulated as follows: Various scientists have conducted empirical studies in an attempt to understand Renewable Energy, sustainable development goals, climate change, Renewable Energy enterprise [31-35] but with less focus on Renewable Energy enterprise in quest of creating a framework nor less focus on mapping the Renewable Energy ecosystem with Sustainable Development goals and societal factors within the South African context theoretically, which the current study fulfils. Studies have been conducted globally and within African context within the Renewable Energy, Renewable Energy enterprise and sustainable development goals $[6,7,20,21,24,25$, 
34, 36] with non-existent focus particularly within the South African context in formulation of the ecosystem nor mapping the sustainable development goals utilising the ecosystem.

Table 1: Findings of the ecosystem for environmental entrepreneurship

\begin{tabular}{|c|c|}
\hline $\begin{array}{l}\text { The theoretical ecosystem } \\
\text { of renewable energy } \\
\text { enterprise }\end{array}$ & $\begin{array}{l}\text { Contextualisation of theoretical } \\
\text { ecosystem Renewable rergy } \\
\text { enterprise to South African context }\end{array}$ \\
\hline $\begin{array}{l}\text { Market incentives } \\
\text { Demand and supply of } \\
\text { renewable energy services }\end{array}$ & ficial development assistance. \\
\hline $\begin{array}{l}\text { Infrastructure governance } \\
\text { Government subsidies [ } 11 \text {, } \\
37]\end{array}$ & $\begin{array}{l}\text { Empowerment of previously } \\
\text { disadvantaged groups, i.e. women, } \\
\text { people of colour and disabled people } \\
\text { Awareness conferences, symposiums }\end{array}$ \\
\hline $\begin{array}{l}\text { Best practices/lessons learnt } \\
\text { from developing countries. }\end{array}$ & $\begin{array}{l}\text { Human resource development policies } \\
\text { and BBBEE }\end{array}$ \\
\hline $\begin{array}{l}\text { Financial support } \\
\text { Venture capital } \\
\text { Budget provisions, grants, } \\
\text { loans, equity financing [36] }\end{array}$ & $\begin{array}{l}\text { South African Government, subsidies } \\
\text { Development Bank of Southern Africa } \\
\text { (DBSA), Private energy entities, } \\
\text { partners and cooperatives financial } \\
\text { support. }\end{array}$ \\
\hline $\begin{array}{l}\text { Alternative forms of } \\
\text { Energy } \\
\text { Solar Energy [21] } \\
\text { Off-grid (Mini-grid) } \\
\text { Saurian Lilting lamp } \\
\text { [38;39] }\end{array}$ & $\begin{array}{l}\text { Mitigation programmes with local } \\
\text { municipalities, baseline studies, solar } \\
\text { Energy }\end{array}$ \\
\hline $\begin{array}{ll}\text { Power plants [38] } & \\
\text { Biomass } & \\
\text { Renewable } & \text { powered } \\
\text { irrigation system } & \end{array}$ & $\begin{array}{l}\text { Stakeholder (Green youth Indaba local } \\
\text { government, Department of Energy, } \\
\text { Department of environmental affairs, an } \\
\text { innovation hub }\end{array}$ \\
\hline $\begin{array}{l}\text { Imported Hydropower } \\
\text { generation } \\
\text { Rural Energy Enterprise } \\
\text { Development (AREED }\end{array}$ & \\
\hline
\end{tabular}

\section{Methodology}

The research methodology followed was in the form of systematic review. The rationale for using a systematic review as a methodology afforded the authors access to the various methodologies and outcomes within the areas of renewable energy enterprises and sustainable development goals. This enabled the researchers to formulate a framework with triangulation of efforts from previous researchers. Furthermore, the rationale for systematic review is to explore the area under investigation. The systematic review as a methodology was beneficial, especially during the COVID-19 pandemic, which has affected the entire world, as interviews or questionnaires would not have succeeded during these challenging times. The use of online data collection still poses challenges due to social inequalities and the majority of people not having access to emails or not being able to afford online video platforms in South Africa.
A systematic literature review was considered as the Research methodology of the current research paper which focussed on peer-reviewed articles utilising search engines such as Google scholar, Energy policy, Journal of cleaner production, Renewable and Sustainable Energy Reviews, Renewable Energy, Energy, Sustainability and Society. The introduction and findings were used to select the relevant articles for inclusion. A theoretical review was conducted through a literature review of which $n=47$ sources (peer-reviewed articles) met the criteria that the researchers set for ecosystem or variables sorted from 89 articles. Duplication of results were further removed. The themes were analysed through thematic content analysis, where themes such as key drivers of Renewable Energy enterprise, sustainable development and Renewable Energy enterprise, the applicability of renewable Energy in the South African context as well as access to renewable Energy sorted from 85 peer-reviewed articles are the outcome.

\section{Findings}

Figure 3 illustrates how the most prominent Sustainable Development Goals can be achieved theoretically using the Renewable Energy Enterprise ecosystem. The subsequent section under discussion will the explain thoroughly the mapping thereof.

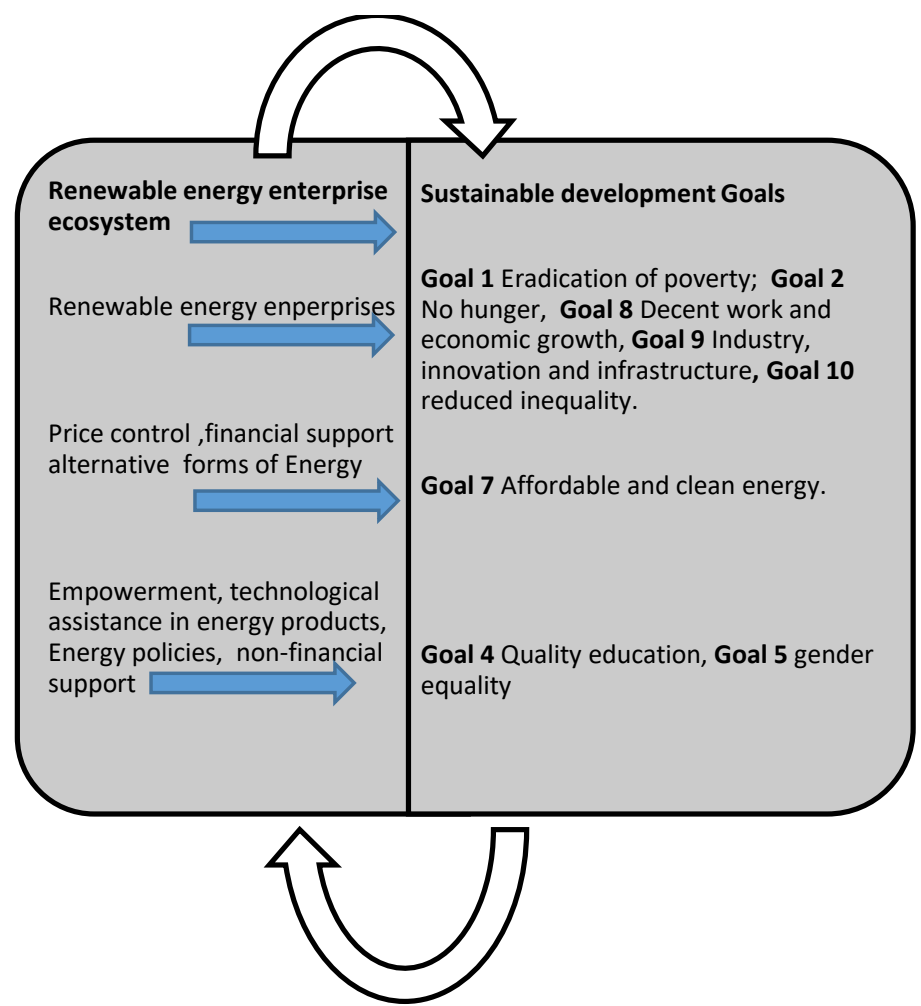

Figure 3: Theoretical Mapping of a renewable energy ecosystem and sustainable development goals

\section{Discussions}

\subsection{Discussion of Renewable Energy enterprise Ecosystem within the South African context}

Through the review of literature, one of the support mechanisms in the sectors is market incentive [39], which can be described by demand and supply or willingness to support the products or services of Renewable Energy. Alternatives, such as 
Solar, off-grid options, especially mini-grids, have been suggested by [40] for rural areas to foster access to Energy.

Majority of business models have not considered the highlevel business planning and strategies, before focusing on specifics of business development [41, 42]. The latter notion will equally contribute to entrepreneurship in Renewable Energy in ensuring enough planning, introducing and managing high-level game-changers as well as policies in regard to entrepreneurship in Renewable Energy.

Natural resources such as wind, solar power stations, and water need to be quantified to measure and form part of the baseline in assessing the readiness of the adoption and diffusion of Renewable Energy. Another sustainable sector that has proven to benefit the planning and implementation of Renewable Energy is the agricultural sector, through irrigations system and implementation of Energy park and monitoring [15].

Electrification plans similarly to what Ghana has implemented [23] can benefit South African context. The electrification plan can be possible with baseline studies and projections or estimation where potential areas may be without electricity [23]. Furthermore, some of the initiatives that can be implemented is the Rural Energy Agency similarly to what Tanzania has implemented [23].

Additional support and efforts made in the South African context is the Renewable Energy White paper, long term mitigation programme scenarios, as well as the Renewable Energy Feed-In Tariff (REFIT) as well as Energy policies and Act to support and regulate the Energy technologies [6, 29, 30, 37]. A generic business framework such as utility Renewable Energy business and customer Renewable Energy business model has been developed to facilitate manufacturing to consumption value chain in quest to support Renewable Energy enterprises in the international markets $[12,13]$.

Infrastructure governance is another support mechanism whereby policies and training can be piloted to the stakeholders. Stakeholders can consist of sustainability specialists, private and public sectors and communities at large. The implementation of a renewable-powered irrigation system [24] can be introduced to minimise challenges of scarcity of resources drawing from [19, 24]. The entrepreneurial confidence in development, consulting and distribution of renewable-powered irrigation system, a budget provision from the government need to support SMEs in the Energy sectors.

The issue of crime and corruption may need to also be factored in budget allocation in the form of investing in security services to safeguard the power stations and Energy technologies.

South Africa is a democratic country where law triumphs all undesirable behaviour and regulate the system. The Energy justice and legal perspective can be implemented when contributing to the sustainable Energy particularly, distributive justice of equal access to resources even to society who cannot afford the services [43].
In $\left[\begin{array}{ll}8 & 10\end{array}\right]$, the author asserts that there should be different tailored types of funding to promote access to Energy in the form of Grants, financing, loans, Equity official development assistance, equity financing and technical assistance in Energy products and services. To translate this mechanism in the South African context, the National Youth development agency, could be a spearhead for funding and include the criteria to promote Energy products, services, consulting or distribution.

The South African national youth development could work hand in hand with Green youth Indaba as well as an Innovation hub where several youth programmes are housed in South Africa, to ensure the sustainability of entrepreneurship in targeting the youth. The authors are proposing the implementation of Green change dynamics as a development programme whereby green readiness of change and managing fear of the unknown within Green initiatives could be introduced to facilitate awareness and training initiatives within Green Energy enterprises, which could be instilled onto the society, to contribute to the level of confidence in Sustainable Energy enterprises sectors.

Clientele and or customers as well as demand and supply serve as the corners and hub of every business incubators. One important factor that will determine the success or failure of a business is customers and customer attitudes, which is often overlooked. However, in the green entrepreneurship field, efforts have been made regarding customer attitude towards green entrepreneurship [44, 45]. Through the analysis of literature, the Utility Renewable Energy business model as well as Customer Renewable Energy business model deemed to be the proposed framework as discovered by scholars in ensuring the monitoring and viability of maintaining clientele with the use of technological assistive programme and stakeholder liaison [9, 12, 13, 46, 47].

Lessons learnt in the form of learning best practices from developed countries, and neighbouring African countries need to be replicated in the South African context, to share the success factors on Energy and advances on technological factors [24]. Furthermore, there should be system management of key holders such as knowledge dissemination through conferences and workshops, the guidance of the search and sponsorship to steer the direction of research and to find how best to formulate policies within the area of Renewable Energy, market niches as well as resource mobilisation such as infrastructure, tax-exempt and micro-financing [48]. The latter mechanisms of financing structures would offer affordable Renewable Energy for a better quality of life to societies at large. In [49], the author asserts that there should be a monitoring tool rating system to ensure that the infrastructure implemented is sustainable. The proposed monitoring tool is sustainable infrastructure rating system [49]. Drawing from this discovery, the authors in the current paper assert the rating system can be used specifically when implementing Energy technologies, services or distribution of renewable Energy tools.

Vat returns, Government subsidies, tax incentives for innovation, price control, demand assurance, venture capital are some of the supporting mechanisms implemented worldwide [911] of which we believe that South Africa can also implement these mechanisms. A need for strong coordination and memorandum of understanding with the countries who have 
developed these mechanisms is needed, to allow exchange programmes within the SMEs in Energy, particularly targeting Youth, Black people, women as well as people living with disabilities as these group, still fall in the designated, previously disadvantaged backgrounds. To broaden the latter perspective, Broad-Based Black Economic Empowerment (BBBEE) will need to also include additional lenses of facilitating Green entrepreneurship and points to be allocated respectively in the form of tendering systems within the advances of Energy sectors.

A further area of consideration is how can different business models such as Pty Ltd (public companies), private companies, close corporation, partnerships, benefit from Renewable Energy at the same time saving the planet. Furthermore, the authors are of the opinions that once the mapping of success factors of different business models can be understood and investigated, support such as lessons learnt, specific funding and non-financial support can be tailored to different Renewable Energy enterprises.

Globalisation in the current context can be seen as a contributing factor, whereby the country such as South African can benefit from markets internationally. In [38], the author echoes the latter statement in supporting imported goods and services such as imported technology for hydropower generation and Biomass. Scholars have demonstrated that through biomass combustion with coal and setting the technologies to exposed heat generate electricity in an effective way [15]. The latter then has further been tested to have saved enterprises when it comes to cost and effective way to the adoption of Renewable Energy [15].

Although imports may also impact on the level of emissions and the cost of Energy services or products, the import of resources serves as the immediate mechanism as South Africa lack enough resources to engage in Energy thematic area effectively. This may imply that concessions and discounted rate may need to be negotiated between two countries embarking on exports and imports. The researchers are of the opinion that there should be public and private organisations willing to train and invest in imports and exports when it comes to Energy enterprises. The introduction of Public-private partnership (PPP) of policies to accelerate the Energy technologies as well as community members being included from the planning to implementation phase in collaboration with NGOs similarly to Nepal's initiatives [32], is needed and may need to be implemented in the South African context.

Saurian lilting low-cost solar lamps as part of renewable Energy [38] serves as a green entrepreneurship initiative that could be explored in the South African context especially in the rural areas and restoring access of Energy to the society.

Further research conducted in other parts of African countries promulgated by UN is African Rural Energy Enterprise Development (AREED) programme and national strategy for the Development of Renewable Energy [23], which South Africa could benefit from the initiative in accelerating entrepreneurship and collaboration in the sector. The need to contribute to society by reducing the electricity bills for those who cannot afford as a form of contributing to the social context when it comes to Energy [19] serves as a priority. Drawing from this idea, the current researchers are of the opinion that once this idea could flourish, this may serve as an incentive for the society to support the enterprises in the sector.

\subsection{Discussions of Renewable Energy enterprise ecosystem to Sustainable development Goals}

In this section, the authors then used the theoretical framework highlighted above through the analysis of literature to map the sustainable development goals to the Renewable Energy ecosystem as depicted in figure 3. A further contribution of the paper is that the authors are arguing that in order to accelerate the sustainable development goals, each thematic area of the green economy needs to be explored and systematically mapped onto the sustainable development goals for an impact. In contribution to the sustainable development goals, the authors are proposing using sustainable development goals as a framework for selecting specific sustainable development goals in mapping the elements of the Renewable Energy enterprise ecosystem.

In order to effect the latter objective the theoretical renewable Energy ecosystem can be used as follows: in order to facilitate the access to the markets, the price of Energy products and services needs to be monitored with set policies and governments subsidies or alternative financial mechanisms upon which the Goal 1 Eradication of poverty, Goal 2 No hunger, Goal 8 Decent work and economic growth, Goal 9 Industry, innovation and infrastructure, Goal 10 Reduced inequality can be accelerated and achieved.

The alternative forms of Energy such as Solar, off the grid, saurian lilting lamp and hydro-powered Energy [21, 30, 38] can further accelerate Goal 7 Affordable and Clean Energy for the better quality of life and livelihoods. Then for further evaluation monitoring and sustainability continuous learning, non-financial support empowering of women and youth, as well as people of colour, can further accelerate Goal 4 Quality education.

\section{Future recommendation}

The next steps will be to test and validate the proposed key accelerators and ways to minimise the barriers that may affect entry to renewable Energy enterprises. Furthermore, scientific empirical data will be needed to test the theoretical contribution of the mapping of sustainable goal with renewable Energy as Green economy thematic area. Furthermore, research on which type of business survives and gets on the markets quick receiving enough support serves as a future research agenda.

\section{Conclusion}

The paper explored various works of literature building the ecosystem through the elements highlighted by most researchers in the field of Renewable Energy enterprises or business ventures. Enabling the green economy involves innovation [17], which in the current study, Renewable Energy enterprise ecosystem serves as the innovation the current authors are proposing. The researchers are of the opinion that once this milestone of capacity building in terms of climate change, and the Green economy is fully implemented then this mechanism can be a wheel to Renewable Energy ecosystem in the transition to green economy. 
The theoretical ecosystem consists of accelerators, societal factors, sustainable development goals, as well as selected business models. The latter ecosystem was then contextualised in the South African context for a complete framework. Some of the accelerators of Renewable Energy are financial and non-financial support mechanisms, generic business models such as customers and demand and monitoring. In answering how can theoretical Renewable Energy enterprise ecosystem be contextualised in the South African context research question: The applicability in the South African context was discussed highlighting the access to Energy by the society at large through reducing of inequality, entrepreneurship and eradication of poverty in drawing from sustainable development goals. In answering the research question: How can Renewable Energy enterprise contribute to sustainable development goals theoretically: Is through the relevant theoretical contribution of eradication of poverty, decent work for all, access to clean and affordable Energy as well as the quality of education. From the analysis of literature rating system, quantification and measurable goals need to be in place to ensure that the plans for implementation of the Renewable Energy are in place. The researchers are then proposing that entrepreneurial markets to be enabled in this arena, and that is where the motives of entrepreneurship would highly contribute to the sense of social gain and uplift and contributing to sustainable development goals with less attention on profit generation.

The benefits of Renewable Energy, as explained above, can benefit people living in rural area through better quality of living and health. Majority of people living in Bangladesh use kerosene, candle and often have to walk a long distance to fetch wood for cooking, Renewable Energy through natural resources such as biogas, the solar, wind, hydropower can benefit the society of rural of Bangladesh [21]. The latter benefits can also benefit most part of rural areas, and some townships in South Africa as some communities are still using candles, paraffin stove and often have to fetch water and wood to cook.

\section{Conflict of Interest}

The authors declare no conflict of interest

\section{Acknowledgment}

IEEM, IEEE 2019 conference motivated and sparked the need to produce another paper emerging from Green entrepreneurship paper the authors presented and published as well as the emerging paper on environmental entrepreneurship the authors produced to be included on Scopus special review. The spark of an idea led to authors focusing on one Green economy thematic area, which is Energy, and refining the research to focus only on the enterprise within the Energy sector. Furthermore, large parts of the paper were presented through poster presentation during 1st annual French South Africa Innovation days held in South Africa CSIR December 2019. The authors will like to thank the coordinators and planners of the latter event. Furthermore, the Authors will like to give thanks to their respective higher learning institutions namely Rhodes University and University of South Africa.

\section{References}

[1] C.D. Diale, G. Kanakana-Katumba, R.W. Maladzhi. "Green Entrepreneurship Model Utilising the System Dynamics Approach: A Review," in 2019 IEEE International Conference on Industrial Engineering and Engineering Management (IEEM) 384-389. (IEEE), 2019, December. doi.org/10.1109/IEEM44572.2019.8978804.

[2] A. Kumar, B. Sah, A.R. Singh, Y. Deng, X. He, P. Kumar, R.C Bansal. "A review of multi criteria decision making (MCDM) towards sustainable renewable energy development," Renewable and Sustainable Energy Reviews, 69, 596-609, 2017. doi.org/10.1016/j.rser.2016.11.191.

[3] Rural electrification. retrieved from https://en.wikipedia.org/wiki/Rural_electrification, accessed September, 2020

[4] J. Amankwah-Amoah. Solar Energy in sub-Saharan Africa: "The challenges and opportunities of technological leapfrogging," Thunderbird International Business Review, 57(1), 15-31, 2015. doi.org/10.1002/tie.21677.

[5] G. Nhamo. "Green economy readiness in South Africa: A focus on the national sphere of government". International Journal of African Renaissance Studies-Multi-, Inter-and Transdisciplinarity," 8(1), 115-142, 2013 doi.org/10.1080/18186874.2013.834628.

[6] M. Engelken, B. Römer, M. Drescher, I.M Welpe, A. Picot. "Comparing drivers, barriers, and opportunities of business models for renewable energies: A review," Renewable and Sustainable Energy Reviews, 60, 795809, 2016. doi.org/10.1016/j.rser.2015.12.163.

[7] C. Herbes, V. Brummer, J. Rognli, S. Blazejewski, N. Gericke. "Responding to policy change: New business models for renewable energy cooperativesBarriers perceived by cooperatives' members," Energy Policy, 109, 82-95, 2017. doi.org/10.1016/j.enpol.2017.06.051.

[8] A.R Nunes, K. Lee, T. O'Riordan. "The importance of an integrating framework for achieving the Sustainable Development Goals: the example of health and well-being," BMJ global health, 1(3), e000068, 2016. doi.org/10.1136/bmjgh-2016-000068.

[9] H. Gujba, S. Thorne, Y. Mulugetta., K. Rai, Y. Sokona. "Financing low carbon energy access in Africa," Energy Policy, 47, 71-78, 2012. doi.org/10.1016/j.enpol.2012.03.071.

[10] M. Loock. "Going beyond best technology and lowest price: on renewable energy investors' preference for service-driven business models," Energy Policy 40, 21-27, 2012. doi.org/10.1016/j.enpol.2010.06.059.

[11] P.R Walsh. "Innovation Nirvana or Innovation Wasteland? Identifying commercialisation strategies for small and medium renewable energy enterprises," Technovation, 32(1), 32-42, 2012.

[12] F. Yu, Y. Guo, K. Le-Nguyen, S.J. Barnes W. Zhang. "The impact of government subsidies and enterprises' R\&D investment: A panel data study from renewable Energy in China,”. Energy Policy, 89, 106-113, 2016. doi.org/10.1016/j.enpol.2015.11.009.

[13] M. Richter. "Utilities' business models for renewable Energy: A review," Renewable and Sustainable Energy Reviews, 16(5), 2483-2493, 2012. doi.org/10.1016/j.rser.2012.01.072.

[14] M. Richter. "German utilities and distributed PV: how to overcome barriers to business model innovation," Renewable Energy 55, 456-466, 2013. doi.org/10.1016/j.renene.2012.12.052.

[15] A. Masini, E. Menichetti. "The impact of behavioural factors in the renewable energy investment decision making process: Conceptual framework and empirical findings," Energy Policy, 40, 28-38, 2012. doi.org/10.1016/j.enpol.2010.06.062.

[16] G. Tate, A. Mbzibain, S. Ali. "A comparison of the drivers influencing farmers' adoption of enterprises associated with renewable Energy," Energy Policy, 49, 400-409, 2012. doi.org/10.1016/j.enpol.2012.06.043.

[17] UNEP. "United nations Environment Programme 2004 annual report. United Nations environment report". Retrieved 29 Nov 2018 from https://wedocs.unep.org/bitstream/handle/20.500.11822/22353/2004_Evalu ation Report.pdf?sequence=1\&isAllowed $=\mathrm{y}, 2005$.

[18] B. J. Anthony, M. A Majid. "Development of a Green ICT Model for Sustainable Enterprise Strategy," Journal of Soft Computing and Decision Support Systems, 3(3), 1-12, 2016.

[19] N. Kajee, E. Sobngwi, A. Macnab, AS Daar. "The Developmental Origins of Health and Disease and Sustainable Development Goals: mapping the way forward," Journal of developmental origins of health and disease, (9)1, 59,2018. doi.org/10.1017/S2040174417000630.

[20] S. O. Oyedepo. "Energy and sustainable development in Nigeria: the way forward," Energy, Sustainability and Society, 2(1), 15, 2012 doi.org/10.1186/2192-0567-2-15.

[21] K.J. Hancock. "The expanding horizon of renewable Energy in sub-Saharan Africa: Leading research in the social sciences," Energy Research \& Social Science, 5, 1-8, 2015. doi.org/10.1016/j.erss.2014.12.021.

[22] MAH Mondal, L.M Kamp, N.I .Pachova, "Drivers, barriers, and strategies for implementation of renewable energy technologies in rural areas in Bangladesh-An innovation system analysis,". Energy Policy, 38(8), 46264634, 2010 
[23] C.A. Gabriel, J. Kirkwood. "Business models for model businesses: Lessons from renewable energy entrepreneurs in developing countries," Energy Policy, 95, 336-349, 2016

[24] J. Haselip, D. Desgain, G. Mackenzie. "Non-financial constraints to scalingup small and medium-sized energy enterprises: Findings from field research in Ghana, Senegal, Tanzania and Zambia," Energy Research \& Social Science, 5, 78-89, 2015. doi.org/10.1016/j.erss.2014.12.016.

[25] L. Agbemabiese, J. Nkomo, Y. Sokona. "Enabling innovations in energy access: An African perspective," Energy Policy, 47, 38-47, 2012 doi.org/10.1016/j.enpol.2012.03.051.

[26] T. Dodd, M. Orlitzky, T. Nelson. "What stalls a renewable energy industry? Industry outlook of the aviation biofuels industry in Australia, Germany, and the USA," Energy Policy, 123, 92-103, 2018. doi.org/10.1016/j.enpol.2018.08.048.

[27] A. Aslani, A. Mohaghar. "Business structure in renewable energy industry: key areas," Renewable and Sustainable Energy Reviews. 27, 569-575, 2013. doi.org/10.1016/j.rser.2013.07.021.

[28] T. Helms. "Asset transformation and the challenges to servitize a utility business model," Energy Policy, 91, 98-112, 2016 doi.org/10.1016/j.enpol.2015.12.046.

[29] A. Pegels. "Renewable Energy in South Africa: Potentials, barriers and options for support". Energy policy, 38(9), 4945-4954, 2010 doi.org/10.1016/j.enpol.2010.03.077.

[30] S. Khennas. "Understanding the political economy and key drivers of energy access in addressing national energy access priorities and policies: African Perspective," Energy Policy, 47, 21-26, 2012 doi.org/10.1016/j.enpol.2012.04.003.

[31] M.O.A González, J. S.Gonçalves, R.M Vasconcelos (2017). "Sustainable development: Case study in the implementation of renewable energy in Brazil”. Journal of Cleaner Production, 142, 461-475, 2017 doi.org/10.1016/j.jclepro.2016.10.052

[32] G. Lakshmi, S. Tilley. "The "power" of community renewable energy enterprises: The case of Sustainable Hockerton Ltd,". Energy Policy, 129, 787-795, 2019. doi.org/10.1016/j.enpol.2019.02.063

[33] R. Liu, L. He, X. Liang, X. Yang, Y. Xia, Y. "Is there any difference in the impact of economic policy uncertainty on the investment of traditional and renewable energy enterprises?-A comparative study based on regulatory effects". Journal of Cleaner Production, 255, 120102, 2020 doi.org/10.1016/j.jclepro.2020.120102

[34] Z.A Elum, A.S. Momodu. "Climate change mitigation and renewable energy for sustainable development in Nigeria: A discourse approach," Renewable and Sustainable Energy Reviews, 76, 72-80, 2017 doi.org/10.1016/j.rser.2017.03.040

[35] X.L. Xu, C.K Liu. "How to keep renewable energy enterprises to reach economic sustainable performance: from the views of intellectual capital and life cycle," Energy, Sustainability and Society, 9, 7, 2019. doi.org/10.1186/s13705-019-0187-2.

[36] G. Schwerhoff, M. Sy. "Financing renewable energy in Africa-Key challenge of the sustainable development goals,". Renewable and Sustainable Energy Reviews, 75, 393-401, 2017. doi.org/10.1016/j.rser.2016.11.004.

[37] H.M. Liou, (2010). "Policies and legislation driving Taiwan's development of renewable Energy,". Renewable and Sustainable Energy Reviews, 14(7), 1763-1781, 2010. doi.org/10.1016/j.rser.2010.02.013.

[38] S. Choudhary, N. Patil. "Green entrepreneurship: role of entrepreneurs in energy economics in Nepal,". Annual Research Journal of Symbiosis Centre for Management Studies, 3(1), 166-175, 2015.

[39] N. Bosma, H. Crijns., T. Holvoet. Global Entrepreneurship Monitor 2011 Report for Belgium \& Flanders, 2013.

[40] S.C Bhattacharyya, D. Palit (Eds.). Mini-grids for rural electrification of developing countries: analysis and case studies from South Asia, Springer, 2014.

[41] H. Chesbrough. "Business model innovation: opportunities and barriers. Long range planning", 43(2-3), 354-363, 2010. doi.org/10.1016/j.lrp.2009.07.010.

[42] J. Leschke. "Business model mapping: A new tool to encourage entrepreneurial activity and accelerate new venture creation," Journal of Marketing Development and competitiveness, 7(1), 18-26, 2013.

[43] L. Guruswamy. "Energy justice and sustainable development". Colo. J. Int'l Envtl. L. \& Pol'y, 21, 231, 2010.

[44] M. Lenox, J.G. York. Environmental entrepreneurship, The Oxford handbook of business and natural environment, 70-92, 2011.

[45] J.K. Hall, G.A. Daneke, M.J. Lenox. "Sustainable development and entrepreneurship: Past contributions and future directions,". Journal of $\begin{array}{llll}\text { business } & \text { venturing, } & \mathbf{2 5}(5), \quad 439-448, & 2010 .\end{array}$ doi.org/10.1016/j.jbusvent.2010.01.002.

[46] S.T Bryant, K. Straker, C. Wrigley. "The typologies of power: Energy utility business models in an increasingly renewable sector,". Journal of Cleaner Production, 195, 1032-1046, 2018. doi.org/10.1016/j.jclepro.2018.05.233.

[47] P. Gsodam, R. Rauter, R.J. Baumgartner. "The renewable energy debate: how Austrian electric utilities are changing their business models," Energy, Sustainability and Society, 5(1), 1-12, 2015. doi.org/10.1186/s13705-0150056-6.

[48] R.A Suurs. "Motors of sustainable innovation: Towards a theory on the dynamics of technological innovation systems," Utrecht University, 2009

[49] J. M Diaz-Sarachaga, D. Jato-Espino, D. Castro-Fresno. "Methodology for the development of a new Sustainable Infrastructure Rating System for Developing Countries (SIRSDEC)". Environmental Science \& Policy, 69, 65-72, 2017. doi.org/10.1016/j.envsci.2016.12.010. 